\title{
Microbial diversity and functionally distinct groups in produced water from the Daqing Oilfield, China
}

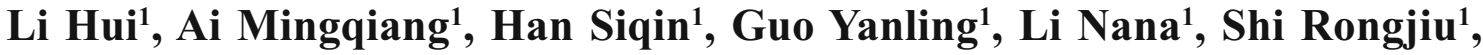 \\ Zeng Xiangling ${ }^{1}$, Leng Shengbing ${ }^{1}$, Zhao Jinyi², Liu Xiaobo² and Zhang \\ Ying ${ }^{1 *}$
}

${ }^{1}$ Key Laboratory of Pollution Ecology and Environment Engineering, Institute of Applied Ecology, Chinese Academy of Sciences, Shenyang, Liaoning 110016, China

${ }^{2}$ Daqing Oilfield Co. Ltd., Daqing, Heilongjiang 163414, China

(C) China University of Petroleum (Beijing) and Springer-Verlag Berlin Heidelberg 2012

\begin{abstract}
The microbial community structure and functionally distinct groups in three kinds of produced water samples from the shallow, mesothermic and low-salinity Daqing oil reservoir were systematically evaluated using both culture-dependent and culture-independent methods. Sequence analysis of the $16 \mathrm{~S}$ rRNA genes indicated that the bacterial library was dominated by Acinetobacter and Arcobacter and the archaeal community was dominated by Methanosaeta and Methanolinea. Two isolated methanogens were closely related with Methanothermobacter thermautotrophicus and Methanoculleus receptaculi. The fermentative bacteria were identified as Pseudomonas, Haloanaerobium, Alcalibacter, Arcobacter, and Pannonibacter. The predominant nitrate-reducing bacteria fell within the genus Pseudomonas. The dominant members of the cultured hydrocarbon-oxidizing bacteria were phylogenetically associated with Micrococcus, Pseudomonas, and Bacillus. Enrichments of biosurfactants and biopolymer producing groups mainly yielded Pseudomonas, Bacillus, and Acenitobacter-related members. The functional groups related to polymer degradation were also affiliated with Pseudomonas and Bacillus. Results from this study provide the fresh insight into the diversity of microbial communities in Daqing petroleum reservoirs. The vast pool of functional strains retrieved in this study was presumed to include the promising strains that could be applied in microbial-enhanced oil recovery in future.
\end{abstract}

Key words: Petroleum microbiology, 16S rRNA gene diversity, methanogens, bio-surfactants producing bacteria, biopolymer-producing bacteria, nitrate-reducing bacteria

\section{Introduction}

Over the past decades, a body of observations have highlighted the great diversity of indigenous microorganisms in subsurface petroleum reservoirs, as well as in the exogenous microorganisms introduced to reservoirs in drilling operations and from water flooding in oil production (Stetter et al, 1993). Physiological types isolated from these special biotopes include fermentative organisms, methanogens, manganese and iron reducers, acetogens, sulphate reducers, aerobic organisms and nitrate reducers (for reviews see Magot et al, 2000). Nevertheless, our current knowledge of the diversity and in situ activities of the microorganisms present in these particular subsurface ecosystems is still limited. The predominant carbon sources used by microorganisms are not

*Corresponding author. email: yzhang@iae.ac.cn

Received February 15, 2012 well defined, and the complex oil field food chain has not yet been understood.

The various aerobic and anaerobic groups of microorganism in oil reservoirs are functionally related to oil hydrocarbons degradation, oil-releasing agents (gas, fatty acids, alcohols, polysaccharides and biosurfactants) synthesis, and the biocontrol of the pipeline corrosion caused by sulfide production (Magot et al, 2000). The technology known as microbial enhanced oil recovery (MEOR) has been applied by either the injection of selected microorganisms with their nutrients into the target petroleum reservoir, or simply the injection of microbial nutrients into the target reservoir to stimulate those indigenous microorganisms that have an oil-releasing capacity. Laboratory investigations and field trials, in close collaboration with the petroleum industry, have indicated that the in situ biophysical and biochemical activities of these microorganisms, as well as their viability, have contributed to an enhancement of oil recovery (Sen, 
2008; Brown, 2010). To understand these activities, the knowledge of the structure of microbial communities in petroleum reservoirs is of great importance.

Daqing Oilfield Co., the largest oil subsidiary of PetroChina, is located in northeast of China, and has maintained an annual crude output of around 40 million tonnes since 2008. In several previous studies, the microbial community structure in produced waters from Daqing Oilfield has been primarily investigated by culture-dependent methods (Zhang et al, 2008). However, relatively little information is available on the composition of microbial assemblages in this unique subsurface environments, which is partly due to the reliance on cultured-based methods for the recovery and identification of individual oil field isolates and the focus on specific physiological groups of microorganisms, such as methanogens and fermentative microorganisms, rather than the entire subsurface microbial community. The application of various molecular techniques has allowed a more complete characterization of the microbial assemblages inhabiting in deep-seated oil reservoirs, and evidence has increasingly indicated that culture-independent techniques, in particular the analysis of retrieved 16S rRNA genes, are effective in characterizing complex microbial assemblages in environmental samples.

$16 \mathrm{~S}$ rDNA sequence analysis has widely been used to characterize microbial assemblages from high-temperature $\left(>70^{\circ} \mathrm{C}\right.$ ) and saline petroleum reservoirs (Orphan et al, 2000; $\mathrm{Li}$ et al, 2007) and low-temperature and freshwater petroleum reservoirs (Voordouw et al, 1996; Grabowski et al, 2005). A parallel measurement using culture-based enrichments, $16 \mathrm{~S}$ rRNA gene sequence analysis and oligonucleotide matrix array hybridization methods was carried out to investigate the microbial groups encompassing key genera of thermophilic bacteria and archaea of a continental high-temperature oil reservoir in Western Siberia, Russia (Bonch-Osmolovskaya et al, 2003). A comparable study of the microbial community in a low-temperature, low-salinity and biodegraded petroleum reservoir from a Western Canadian Sedimentary Basin has been reported, which employed a multidisciplinary approach including chemical and geochemical examinations, biodegradation studies, and culture-based and 16S rRNA gene analyses (Grabowski et al, 2005). However, few comparable studies have been reported in shallow, mesothermic, lowsalinity oil reservoirs. There must be a unique microbial community in this geochemically distinct oil reservoir.

The specific aim of this study is to reveal the bacterial and archaeal community structure in produced water from mesothermic, low-salinity oil reservoirs in the Daqing Oilfield, by construction of $16 \mathrm{~S}$ rDNA libraries and further amplified ribosomal DNA restriction analysis (ARDRA), and also, to isolate indigenous functionally distinct groups that have potential oil field use (especially in MEOR) by culturebased methods.

\section{Materials and methods}

\subsection{Site description and reservoir conditions}

Daqing Oilfield is located in the northeast of China $\left(45^{\circ} 46^{\prime}\right.$ $\left.\mathrm{N}, 124^{\circ} 19^{\prime} \mathrm{E}\right)$. Production depths at this site range from 900 to $1,200 \mathrm{~m}$ and the in situ fluid temperatures are between 40 and $45^{\circ} \mathrm{C}$. Crude oils in the Daqing Oilfield are recovered mainly by water flooding, which has been continuously flooded with recycled produced water. For increasing oil production, polymer flooding operations have been implemented in one thirds of production blocks since 1998. There still exist some special blocks in which oil is produced by water flooding, but the produced water collected from these water flooding reservoirs contains some polymers due to the belowground connection with some reservoirs where polymer flooding operations were conducted. These special blocks were referred as transitional zone in the following text.

\subsection{Sample collection}

Produced water were collected directly from three distinct reservoir types, that is, a water flooding reservoir, a polymer flooding reservoir and the transitional zone. Ten wells were randomly selected from each block, and 5 L produced water were collected from each well and mixed together. Samples were taken through sampling valves located on the well head into pre-rinsed barrels filled with nitrogen, after flushing the lines for at least $15 \mathrm{~min}$. The barrels were filled completely with the oil/water/gas mixture (the water cut was around $90 \%$ ), then sealed to maintain anoxic conditions. The barrels were transported back to the laboratory at ambient temperature and immediately separated into $1 \mathrm{~L}$ sterile bottles under protection of pure nitrogen. Samples used for community DNA extraction and construction of 16S rDNA libraries were kept at $-20^{\circ} \mathrm{C}$ until use, while, the samples for isolation of functionally distinct groups were stored at $4{ }^{\circ} \mathrm{C}$ and were taken for enrichment culture within one week of collection.

\subsection{Total community DNA extraction and 16S rDNA fragments amplification}

Phase separation of the oil-water emulsion was accomplished by heating to $70{ }^{\circ} \mathrm{C}$ for 10 to $20 \mathrm{~min}$ in 2-liter Teflon separatory funnels (Fisher, Houston, Tex.). The water phase was separated from crude oil by decantation at room temperature. Microbial biomass from approximately $3.0 \mathrm{~L}$ of the water phase was collected by centrifugation at $12,000 \times g$ at $4{ }^{\circ} \mathrm{C}$. The resulting cell pellets were suspended in $1,000 \mu \mathrm{L}$ of DNA extraction buffer (100 mol/L Tris- $\mathrm{HCl}$ [pH 8.0], 100 $\mathrm{mmol} / \mathrm{L}$ sodium EDTA [pH 8.0], $100 \mathrm{~mol} / \mathrm{L}$ sodium phosphate [pH 8.0], $1.5 \mathrm{~mol} / \mathrm{L} \mathrm{NaCl}, 1 \% \mathrm{CTAB})$ and treated with $3 \mu \mathrm{L}$ of lysozyme $(300 \mathrm{mg} / \mathrm{mL})$ and $10 \mu \mathrm{L}$ of proteinase $\mathrm{K}(10 \mathrm{mg} /$ $\mathrm{mL}) .100 \mu \mathrm{L}$ of $20 \%$ SDS was added and the samples were incubated in a $65{ }^{\circ} \mathrm{C}$ water bath for $2 \mathrm{~h}$ with gentle end-overend inversions every 15 to $20 \mathrm{~min}$. The supernatants were collected after centrifugation at $6,000 \times g$ for $10 \mathrm{~min}$ at room temperature and transferred into another micro centrifuge tubes. Supernatants were mixed with an equal volume of chloroform isoamyl-alcohol $(24: 1, \mathrm{v} / \mathrm{v})$. The aqueous phase was recovered by centrifugation and precipitated with 0.6 volume of isopropanol at room temperature for $1 \mathrm{~h}$. The pellet of crude nucleic acids was obtained by centrifugation at $16,000 \times \mathrm{g}$ for $20 \mathrm{~min}$ at room temperature, washed with cold $70 \%$ ethanol, and resuspended in a TE buffer to give a 
final volume of $50 \mu \mathrm{L}$. The crude DNA extract was subjected to agarose gel electrophoresis and the DNA bands were excised, melted and purified by TaKaRa agarose gel DNA purification kit (Takara Bio. Inc., Dalian, China) according to the manufacturer's instructions.

The total community DNA extracted from three produced water samples were used for amplification of $16 \mathrm{~S}$ rRNA genes. Small-subunit rRNA genes were amplified by PCR using Bacteria-specific primer (27f, 5'-AGAGTTTGATCCTGGCTCAG-3'; 1492r, 5'- GGTTACCTTGTTACGACTT-3') (Lane et al, 1991) and Archaea-specific primer (751f, 5' - CCGACGGTGAGRGRYGAA - 3'; 1406 r, 5' ACGGGCGGTGWGTRCAA -3') (Baker et al, 2003). The final $25 \mu \mathrm{L}$ reaction mixture contained $1 \mu \mathrm{L}$ of template DNA, $20 \mathrm{pmol} / \mathrm{L}$ of each primer, $200 \mu \mathrm{mol} / \mathrm{L}$ deoxynucleoside triphosphates, $2.5 \mathrm{U}$ of Taq DNA polymerase, and the buffer supplied with the enzyme (Takara Bio. Inc., Dalian, China). The bacterial 16S rRNA genes were amplified using the following conditions: After an initial denaturation at $94{ }^{\circ} \mathrm{C}$ for $5 \mathrm{~min}$, nucleic acids were amplified for 35 cycles ( 1 min of denaturation at $94{ }^{\circ} \mathrm{C}, 1 \mathrm{~min}$ of annealing at $55^{\circ} \mathrm{C}$, and 2 min of elongation at $72{ }^{\circ} \mathrm{C}$ ), followed by a final extension step at $72{ }^{\circ} \mathrm{C}$ for $8 \mathrm{~min}$. The amplification program for Archaeal 16S rDNA consisted of a 5 min denaturing step at $95^{\circ} \mathrm{C}$ followed by 30 cycles of $1 \mathrm{~min}$ at $95^{\circ} \mathrm{C}, 1 \mathrm{~min}$ at $55^{\circ} \mathrm{C}$, and $90 \mathrm{~s}$ at $72^{\circ} \mathrm{C}$.

\subsection{Construction and ARDRA analysis of 16S rDNA libraries}

PCR products of rrs genes were checked on agarose gel stained with ethidium bromide, followed by purification with TaKaRa agarose gel DNA purification kit (Takara Bio. Inc., Dalian, China). The purified PCR amplicons were ligated into the plasmid vector pMD18-T (Takara Bio. Inc., Dalian, China). Ligation and transformation into Escherichia coli JM 109 competent cells were carried out according to the manufacturer's instructions. Transformants were screened using blue-white selection on LuriaBertani agar plates containing X-Gal (5-bromo-4-chloro3-indolyl-b-D-galactopyranoside), IPTG (isopropyl-bD-thiogalactopyranoside) and $100 \mu \mathrm{g} / \mathrm{mL}$ ampicillin. Approximately 240 and 120 white colonies were picked from the bacterial and archaeal library of each produced water sample, respectively. And thus, a total of 720 and 360 white colonies were selected from the bacterial and archaeal libraries, respectively. Positive inserts were screened by PCR with vector-specific primers M13-47 (5'-CGCCAGGGTTTTCCCAGTCACGAC-3') and RV-M (5'-GAGCGGATAACAATTTCACACAGG-3'). PCR was performed as described above, except that the template was added as whole cells. The products were verified by gel electrophoresis. Amplicons of the expected size were simultaneously digested with the restriction enzymes Afa I and Msp I (5 U of each) for $3 \mathrm{~h}$ at $37{ }^{\circ} \mathrm{C}$ in $20 \mu \mathrm{L}$ reaction mixtures containing $2 \mu \mathrm{L}$ Buffer. The resulting restriction fragment length polymorphism (RFLP) products were separated by $10 \%$ polyacrylamide gel electrophoresis at 80 $\mathrm{V}$ for $45 \mathrm{~min}$. Digital images of the gel were obtained using Gel Doc 2000TM gel documentation systems (Bio-Rad,
Hercules, CA, USA). The banding patterns of the clones were compared manually and clones that produced the same ARDRA pattern were grouped into the same Operational Taxanomic Units (OTUs). The distribution of OTUs present in different clone libraries was determined and used to calculate the Shannon-Weaver index $H=-\sum n_{i} \cdot \ln \left(n_{i}\right)$, where $n_{i}$ is the relative contribution of clone type $i$ to the whole library (Shannon and Weaver, 1949). Coverage is calculated as $C=1-n_{1} / N$, where $n_{1}$ is the number of OTUs and $N$ is the number of individuals in sample (Good, 1953).

\subsection{Sequencing of partial OTUs and phylogenetic analysis}

OTUs occurring more than twice in the libraries were selected for sequence analysis. Template plasmid DNA of representing clones was prepared from overnight cultures of positive transformants by using the Qiaprep Plasmid Miniprep kit (Qiagen, Inc., Chatsworth, Calif.). DNA sequencing was performed with an ABI PRISM BigDye terminator cycle sequencing Ready Reaction kit (Applied Biosystems, Foster City, Calif.) and an ABI PRISM 3700 DNA analyzer (Applied Biosystems). The vector-specific primer M13-47 was used for sequencing. These sequences were checked for chimeric artifacts by the CHECKCHIMERA service provided by the Ribosomal Database Project. Sequences were compared to sequences deposited in the GenBank DNA database by using the BLAST algorithm. The bacterial and archaeal 16S rRNA gene sequences determined in this study were deposited in the GenBank database under accession numbers GQ415364GQ415385 and GQ415357-GQ415363, respectively.

\subsection{Isolation and screening of functionally distinct groups with selective media}

\subsubsection{Methanogens}

Enumeration and isolation of methanogens were performed using the modified basal medium containing the following components (per liter distilled water): $20 \mathrm{~g} \mathrm{NaCl}$, $0.9 \mathrm{~g} \mathrm{MgCl}_{2} \cdot 6 \mathrm{H}_{2} \mathrm{O}, 1.4 \mathrm{~g} \mathrm{MgSO}_{4} \cdot 7 \mathrm{H}_{2} \mathrm{O}, 0.33 \mathrm{~g} \mathrm{KCl}, 0.25 \mathrm{~g}$ $\mathrm{NH}_{4} \mathrm{Cl}, 0.14 \mathrm{~g} \mathrm{CaCl}_{2} \cdot 2 \mathrm{H}_{2} \mathrm{O}, 0.45 \mathrm{~g} \mathrm{KH}_{2} \mathrm{PO}_{4}, 1.0 \mathrm{~mL}$ trace element solution $\mathrm{SL}-10,10 \mathrm{~mL}$ vitamin solution, and 0.5 $\mathrm{mL}$ resazurin $(0.02 \%)$ (Kaster and Voordouw, 2006). The gas phase was $\mathrm{N}_{2} / \mathrm{CO}_{2}(80 / 20, \mathrm{v} / \mathrm{v})$ and the medium was supplemented with $4 \mathrm{~g} \mathrm{NaHCO}_{3}$ per liter. The final $\mathrm{pH}$ was adjusted to 7.0. For cultivation of acetoclastic methanogens, sodium acetate $(30 \mathrm{~mol} / \mathrm{L})$ was added to the medium. Hydrogen oxidation was tested using a gas phase of $\mathrm{H}_{2} / \mathrm{CO}_{2}$ $(80 / 20, \mathrm{v} / \mathrm{v})$ at $100 \mathrm{kPa}$ overpressure. Media were dispensed into Hungate tubes which were subsequently sealed with butyl rubber stoppers. Solid media for roll-tubes and slants were prepared by including $15 \mathrm{~g} \cdot \mathrm{L}^{-1}$ agar in the medium. Vials were autoclaved at $121{ }^{\circ} \mathrm{C}$ for $20 \mathrm{~min}$ and stored at $60{ }^{\circ} \mathrm{C}$ before inoculation of production fluids. Sodium sulfide $\mathrm{Na}_{2} \mathrm{~S}$ $(1.5 \mathrm{mmol} / \mathrm{L})$ was used as a reducing agent. Immediately after inoculation $(5 \%)$, the vials were placed on an ice bath to make a roll tube. Two replicate tubes were inoculated per dilution, and the vials were incubated at $45^{\circ} \mathrm{C}$ for $30-45$ days. Isolation of pure cultures was performed by picking colonies grown in an anaerobically prepared solidified medium as described by Ollivier et al (1997). 


\subsubsection{Fermentative bacteria}

Fermentative growth was tested on $28 \mathrm{~mol} / \mathrm{L}$ fructose (Grabowski et al, 2005). The same basal medium as described in 2.6.1 was used for enrichment of fermentative bacteria. Organic substrates were added from separate, anaerobically prepared, stock solutions.

\subsubsection{Nitrate-reducing bacteria}

Nitrate-reducing bacteria in produced water were enumerated by the most-potable-number (MPN) method using Durham tubes (Li et al, 1997). The modified nitrate broth (NB) was prepared under strict anoxic conditions to grow nitrate-reducing bacteria. The medium included (per liter distilled water): $20 \mathrm{~g}$ peptone, $10 \mathrm{~g}$ beef extract, $1.0 \mathrm{~g} \mathrm{KNO}_{3}, 5 \mathrm{~g} \mathrm{NaCl}, 0.7 \mathrm{~g} \mathrm{KCl}, 10 \mathrm{~g} \mathrm{MgCl}_{2} \cdot 6 \mathrm{H}_{2} \mathrm{O}, 5.4 \mathrm{~g}$ $\mathrm{MgSO}_{4} \cdot 7 \mathrm{H}_{2} \mathrm{O}, 1.0 \mathrm{~g} \mathrm{CaCl}_{2} \cdot 2 \mathrm{H}_{2} \mathrm{O}, \mathrm{pH}$ 7.2-7.5. Two replicate tubes were inoculated per dilution and incubated at $30^{\circ} \mathrm{C}$ for 15 days. Counts of nitrate-reducing bacteria were based on gas production in Durham tubes. Denitrifying bacteria were isolated from the $\mathrm{N}_{2} \mathrm{O}$-accumulated tubes in the highest or semi-highest dilution series and purified on plates of the NB medium solidified with $1.5 \%$ agar.

\subsubsection{Biosurfactant producing bacteria}

Biosurfactant-producing bacteria were primarily enumerated and screened using blood agar plates containing $5 \%$ sterile defibrinated sheep blood (Carrillo et al, 1996) and incubated at $37{ }^{\circ} \mathrm{C}$ for $48 \mathrm{~h}$. Haemolytic activity was detected as the presence of a definite clear zone around a colony. Growth experiments were performed in 250-mL Erlenmeyer flasks, each containing $30 \mathrm{~mL}$ medium including (per liter distilled water): $7.0 \mathrm{~g}\left(\mathrm{NH}_{4}\right)_{2} \mathrm{SO}_{4}, 3.8 \mathrm{~g} \mathrm{Na} \mathrm{HPO}_{4} \cdot 12 \mathrm{H}_{2} \mathrm{O}, 3.5 \mathrm{~g}$ $\mathrm{KH}_{2} \mathrm{PO}_{4}, 0.7 \mathrm{~g} \mathrm{MgSO}_{4} \cdot 7 \mathrm{H}_{2} \mathrm{O}, 0.5 \mathrm{~g}$ yeast extract, and 20.0 $\mathrm{g}$ glucose. The flasks were incubated at $28{ }^{\circ} \mathrm{C}$ on a rotary shaker at $240 \mathrm{rpm}$. Surface tension of the cell-free culture was determined by using a Fisher surface tensiometer (model 20). 2.6.5 Hydrocarbon oxidizing bacteria

Hydrocarbon oxidizing bacteria were selected and screened by modified mineral salt medium with $1 \%$ liquid paraffin $(\mathrm{w} / \mathrm{v})$ as the sole source of carbon (Rozanova and Nazina, 1982). The mineral medium used contained (per liter distilled water): $1.0 \mathrm{~g}\left(\mathrm{NH}_{4}\right)_{2} \mathrm{SO}_{4}, 3.0 \mathrm{~g} \mathrm{Na}_{2} \mathrm{HPO}_{4}$, $2.0 \mathrm{~g} \mathrm{KH}_{2} \mathrm{PO}_{4}, 0.2 \mathrm{~g} \mathrm{MgSO}_{4} \cdot 7 \mathrm{H}_{2} \mathrm{O}, 0.01 \mathrm{~g} \mathrm{CaCl}_{2}, 0.01 \mathrm{~g}$ $\mathrm{FeSO}_{4} \cdot 7 \mathrm{H}_{2} \mathrm{O}$, pH 7.2-7.5. Liquid paraffin refers to a mixture of straight-chain hydrocarbons ( $n$-alkane) containing 10 to 18 carbon atom per molecule. Solid media contained 15 $\mathrm{g} \cdot \mathrm{L}^{-1}$ agar. Bacterial counts were determined by cultivation on agarised media using the spread plate method. The inocula of $0.1 \mathrm{~mL}$ of appropriate dilutions were plated in triplicate. The plates were incubated for $5-7$ days at $45^{\circ} \mathrm{C}$. The grown colonies were enumerated and the average counts being calculated per milliliter of water.

\subsubsection{Polymer producing bacteria}

Selective medium for enumeration and cultivation of presumed biopolymer producing bacteria composed of (per liter of medium): $40 \mathrm{~g}$ sucrose, $0.5 \mathrm{~g} \mathrm{NaNO}_{3}, 1.0 \mathrm{~g}$ yeast extract, $0.5 \mathrm{~g} \mathrm{KH}_{2} \mathrm{PO}_{4}, 0.25 \mathrm{~g} \mathrm{MgSO}_{4} \cdot 7 \mathrm{H}_{2} \mathrm{O}$, pH 7.0. Solid media were prepared by the addition of $15 \mathrm{~g} \cdot \mathrm{L}^{-1}$ agar. Wet and viscous colonies were picked up and preliminarily considered as the biopolymer producing bacteria. The capacity for biopolymer production of the isolates was preliminarily detected by fermentation at $45{ }^{\circ} \mathrm{C}$ for $72 \mathrm{~h}$. The viscosity of the fermented broth was determined by using a Brookfield DV-II viscometer (Tokyo Keiki Seizousyo, Model LVT) fitted with a spindle $(0.5 \mathrm{rps})$ at $30^{\circ} \mathrm{C}$.

\subsubsection{Polyacrylamide degrading bacteria}

Basal mineral salt medium supplemented with hydrolysed polyacrylamide (HPAM) (0.75 g per liter medium) as the sole source of carbon and nitrogen was used for selection of HPAM degrading bacteria. The mineral medium used was previously recommended by Ma et al (2008). $15 \mathrm{~g} \cdot \mathrm{L}^{-1}$ agar were added in the medium to prepare solid plate. The plates were incubated for 5 days at $45^{\circ} \mathrm{C}$, and the colonies that can grow on the selective plates are considered as the presumed HPAM utilizing bacteria. The HPAM degrading ability was tested with fermentation at $45{ }^{\circ} \mathrm{C}$ for 5 days in the liquid culture. The decrease in viscosity of the broth was determined by the Brookfield DV-II viscometer (Tokyo Keiki Seizousyo, Model LVT) fitted with a spindle $(0.5 \mathrm{rps})$ at $30^{\circ} \mathrm{C}$.

\subsection{Identification of pure culture}

Around 10-90 single colonies with variety of morphotypes were randomly selected from each functional group. The genomic DNA from pure culturable isolates was extracted by standard proteinase $\mathrm{K}$, sodium dodecyl sulfate, phenolchloroform procedure. In brief, the cells were collected by centrifugation at 8,000 rpm for $2 \mathrm{~min}$ and resuspended in $597 \mu \mathrm{L}$ of TE buffer, and then $30 \mu \mathrm{L}$ of $10 \%$ SDS and $3 \mu \mathrm{L}$ of proteinase $\mathrm{K}\left(20 \mathrm{mg} \cdot \mathrm{mL}^{-1}\right)$ were added. The mixture was incubated for $1 \mathrm{~h}$ at $37^{\circ} \mathrm{C}$ followed by $10 \mathrm{~min}$ at $65^{\circ} \mathrm{C}$ with $100 \mu \mathrm{L}$ of $5 \mathrm{~mol} / \mathrm{L} \mathrm{NaCl}$ and $80 \mu \mathrm{L}$ of $10 \% \mathrm{CTAB} / \mathrm{NaCl}$ added. An equal volume of chloroform-isoamyl alcohol (24:1) extraction was performed and the mixture was centrifuged at $6,000 \times g$ for $10 \mathrm{~min}$. Precipitation with an equal volume of isopropanol was followed by centrifugation $16,000 \times \mathrm{g}$ for 20 min. The DNA was resuspended in $30 \mu \mathrm{L}$ of TE buffer. $16 \mathrm{~S}$ rDNAs were then amplified by PCR using archaea-specific (751f-1406r) or bacteria-specific (27f-1492r) primers. PCR products were then screened by restriction fragment length polymorphism (RFLP) analysis using enzymes Rsa I and Hae III. The representative phylogenetic types were selected for partial 16S rDNA sequencing. Phylogenetic analysis of cultured isolates was performed as described in 2.5.

\section{Results}

\subsection{Physiochemical characteristics of the Daqing Oilfield}

Daqing Oilfield is a mesothermic reservoir with bottom hole temperatures of 40 to $45^{\circ} \mathrm{C}$. The total dissolved solids of formation water collected from the three kinds of production blocks varied from 5,367 to 7,496 ppm and were slightly alkaline in $\mathrm{pH}$ (Table 1). Produced water belonged to sodium bicarbonate water type with a $\mathrm{NaCl}$ concentration around 3-4 $\mathrm{g} \cdot \mathrm{L}^{-1}$. Saline connate water has been diluted by freshwater that have been injected into the wells, which could explain their low salinity and high bicarbonate content. 
Table 1 Physicochemical characteristics of the water samples obtained from the water flooding reservoir, polymer flooding reservoir and the transitional zone

\begin{tabular}{|c|c|c|c|}
\hline Parameter & Water flooding reservoir & Polymer flooding reservoir & Transitional zone \\
\hline Temperature, ${ }^{\circ} \mathrm{C}$ & 40 & 45 & 42 \\
\hline $\mathrm{pH}$ value & 8.51 & 8.60 & 8.21 \\
\hline $\mathrm{Ca}^{2+}, \mathrm{mg} \cdot \mathrm{L}^{-1}$ & 11.47 & 35.07 & 24.25 \\
\hline $\mathrm{Na}^{+}, \mathrm{mg} \cdot \mathrm{L}^{-1}$ & 1734.93 & 1647.55 & 2430.33 \\
\hline $\mathrm{K}^{+}, \mathrm{mg} \cdot \mathrm{L}^{-1}$ & 24.31 & 18.20 & 27.86 \\
\hline $\mathrm{Mg}^{2+}, \mathrm{mg} \cdot \mathrm{L}^{-1}$ & 12.40 & 5.32 & 10.75 \\
\hline $\mathrm{Cl}^{-}, \mathrm{mg} \cdot \mathrm{L}^{-1}$ & 982.50 & 876.81 & 1678.79 \\
\hline $\mathrm{SO}_{4}{ }^{2-}, \mathrm{mg} \cdot \mathrm{L}^{-1}$ & 30.99 & 27.02 & 34.58 \\
\hline $\mathrm{CO}_{3}^{2-}, \mathrm{mg} \cdot \mathrm{L}^{-1}$ & 359.27 & 243.99 & 318.03 \\
\hline $\mathrm{HCO}_{3}^{-}, \mathrm{mg} \cdot \mathrm{L}^{-1}$ & 2202.26 & 2513.54 & 3070.02 \\
\hline Total dissolved solids, $\mathrm{mg} \cdot \mathrm{L}^{-1}$ & 5408.11 & 5367.47 & 7495.61 \\
\hline Water type & $\mathrm{NaHCO}_{3}$ & $\mathrm{NaHCO}_{3}$ & $\mathrm{NaHCO}_{3}$ \\
\hline Total hardness & 0.80 & 1.10 & 1.05 \\
\hline
\end{tabular}

\subsection{ARDRA analysis of microbial community structure in produced water}

Microbial diversity associated with produced water was analyzed by constructing bacterial and archeael $16 \mathrm{~S}$ rDNA libraries and further ARDRA analysis. Bacterial and archeael 16S rDNA libraries of three water samples were constructed using PCR and DNA extracted directly from produced water as template.

\subsubsection{Bacterial 16S rDNA libraries}

A total of 596 positive clones were selected from bacterial libraries, and were clustered into 85 operational taxonomic units (OTUs) by ARDRA analysis, with 28 OTUs in the polymer flooding reservoir library, 41 in the water flooding reservoir library, and 33 in the transitional zone library. As a result, water flooding sample have the highest $H^{\prime}$ value, and the S-W indices calculated from the other two samples were relatively low (Table 2 ).

Table 2 The number of clones screened from each library and the diversity parameters calculated based on ARDRA analysis

\begin{tabular}{cccccc}
\hline Library & Sample & Number of positive clones & Number of OTUs & Coverage C, \% & $\begin{array}{c}\text { Shannon-Wiener } \\
\text { index } H^{\prime}\end{array}$ \\
\hline \multirow{3}{*}{ Bacterial libraries } & Polymer flooding & 204 & 28 & 90.7 & 1.66 \\
& Transitional zone & 193 & 33 & 86.5 & 1.94 \\
& Water flooding & 199 & 41 & 87.4 & 2.76 \\
\hline \multirow{3}{*}{ Archeael libraries } & Polymer flooding & 81 & 10 & 85.6 & 1.81 \\
& Transitional zone & 75 & 11 & 85.5 & 1.84 \\
& Water flooding & 96 & 17 & 73.7 & 2.20 \\
\hline
\end{tabular}

Dominant OTUs with more than one sequence were selected for sequence analysis. Sequences were blasted in the GeneBank Database, and phylogenetic trees were constructed based on the sequenced $16 \mathrm{~S}$ rDNA and their relatives in the database (Fig. 1). All the sequenced phylotypes in bacterial libraries showed $93 \%$ to $97 \%$ similarity to previously determined rDNA sequences (Table 3). However, of 22 sequenced phylotypes, 7 OTUs had less than $97 \%$ identity to closest matches in GenBank and probably represent novel genera or species. The bacterial group in the produced water was dominated by some mesophilic members, including Acinetobacter, Arcobacter, and Pseudomonas, together with some thermophilic genera, such as Moorella thermoacetica (Firmicutes), and Sulfurospirillum. Among these five groups, Acinetobacter and Pseudomonas were found in all three samples.

The relative contributions of different phylogenetic groups to bacterial communities were shown in Fig. 2 and Table 3. Bacterial composition in the water flooding reservoir, polymer flooding reservoir, and the transitional zone $16 \mathrm{~S}$ rDNA libraries revealed a marked disparity in representation. Samples from wells treated with polymer had the simplest bacterial composition and the lowest diversity. The most frequent phylogenetic group, accounting for $85 \%$ of the polymer flooding library, was closely related to Acinetobacter. 


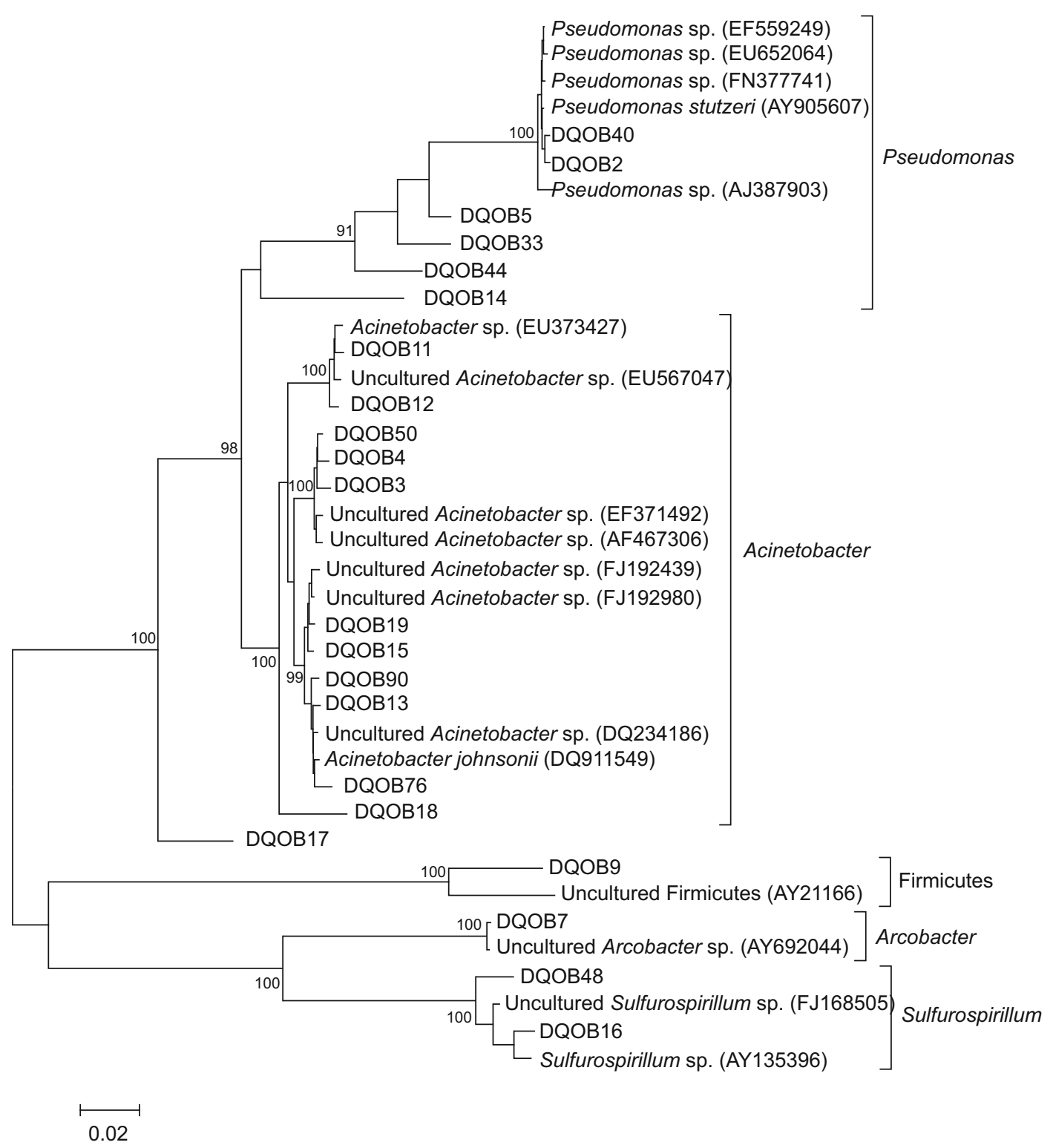

Fig. 1 Phylogenetic tree of sequenced bacterial OTUs

The remaining dominant OTUs are mainly assigned to Pseudomonas (7\%). The water flooding reservoir was also dominated by Acinetobacter (62\%), and the bacteria closely related to Pseudomonas and Sulfurospirillum composed $20 \%$ and $6 \%$ of the library, respectively. Different from the former two, the samples from the transitional zone was dominated by Arcobacter (50\%), followed by Acinetobacter (19\%) and Firmicutes (18\%).

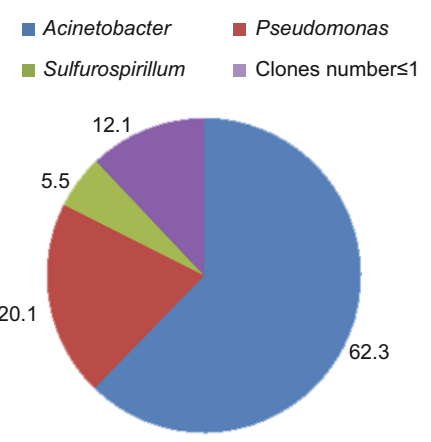

(a) Water flooding reservoir

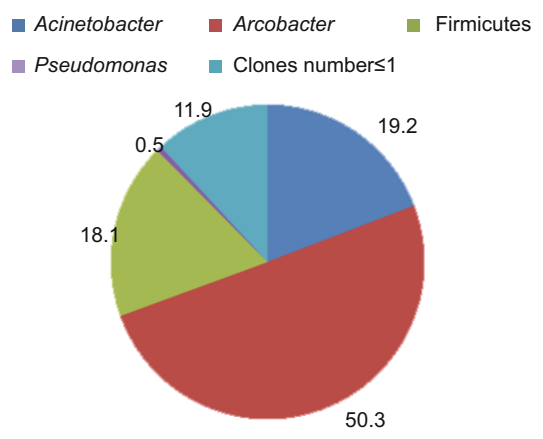

(b) Transitional zone

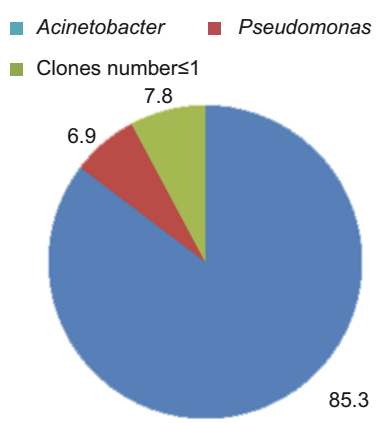

(c) Polymer flooding reservoir

Fig. 2 Relative contributions of different phylogenetic groups to bacterial communities 
要,

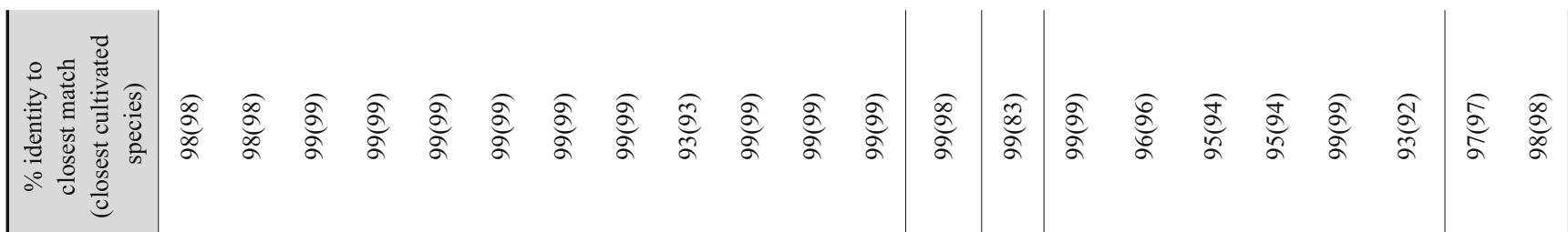

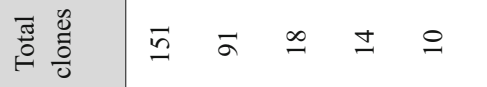

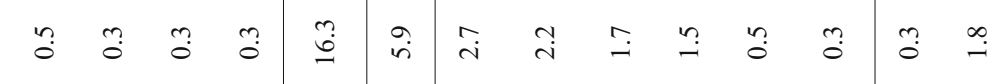
$\mid \begin{array}{ll}\exists \\ 0 \\ 0 \\ 0 \\ 0\end{array}$ 带旁

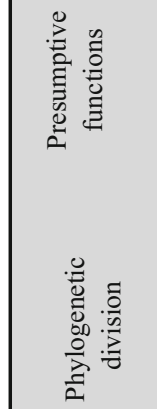

$$
\begin{array}{ll}
\text { in } & n \\
\text { i } & 1 \\
0 & \pm \\
0 & 1 \\
m & + \\
0 & 0 \\
0 & 0 \\
0 & 0
\end{array}
$$

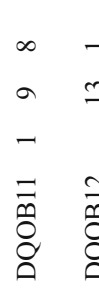

$$
\begin{aligned}
& \begin{array}{l}
- \\
- \\
\sim \\
\frac{m}{0} \\
\frac{0}{0}
\end{array}
\end{aligned}
$$

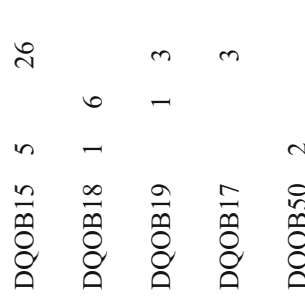

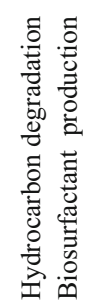

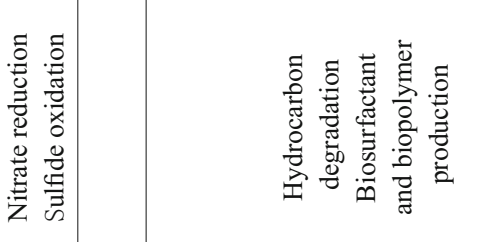

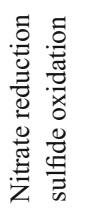




\subsubsection{Archaeal 16S rDNA libraries}

Only 28 archaeal OTUs were identified from a total of 252 positive clones with 10 OTUs in the polymer flooding reservoir library, 17 in the water flooding reservoir library and 11 in the transitional zone library (Table 2).

The sequenced 8 OTUs only clustered within 3 phylogenetic groups, with Methanosaeta as the dominating groups $(65 \%)$. The phylogenetic trees were constructed based on the sequenced $16 \mathrm{~S}$ rDNA and their relatives in the database (Fig. 3). Four distinct ARDRA patterns were revealed from Methanosaeta, all of which were closely (96\%99\%) affiliated with species Methanosaetathermophila. Methanolinea and some unknown genus in phylum Crenarchaeota accounting for $19.4 \%$ and $8.7 \%$ of the library, respectively. Approximately $6.7 \%$ of the OTUs were represented by only one clone. Archaeal community structures in three produced water samples are quite similar, and all of the archeael libraries were dominated by Methanosaeta. Relative contributions of different phylogenetic groups to archaeal communities were shown in Fig. 4 and Table 4.

Table 4 ARDRA types occurring more than twice in archaeal library, their relative contributions to the clone library, and the closest relative in the GenBank database

\begin{tabular}{|c|c|c|c|c|c|c|c|c|c|c|}
\hline \multirow{2}{*}{$\begin{array}{l}\text { Phylogenetic } \\
\text { division }\end{array}$} & \multirow{2}{*}{$\begin{array}{l}\text { Presumptive } \\
\text { functions }\end{array}$} & \multirow{2}{*}{$\begin{array}{l}\text { ARDRA } \\
\text { type }\end{array}$} & \multicolumn{3}{|c|}{$\begin{array}{c}\text { Clones in } \\
\text { samples }\end{array}$} & \multirow{2}{*}{$\begin{array}{c}\text { Total } \\
\text { clones }\end{array}$} & \multirow{2}{*}{$\begin{array}{c}\% \\
\text { clones }\end{array}$} & \multirow{2}{*}{$\begin{array}{l}\text { Closest relative in GenBank } \\
\text { database (accession No.) }\end{array}$} & \multirow{2}{*}{ Closest cultivated species } & \multirow{2}{*}{$\begin{array}{c}\% \text { identity to } \\
\text { closest match } \\
\text { (closest cultivated } \\
\text { species) }\end{array}$} \\
\hline & & & $\mathrm{P}$ & $\mathrm{T}$ & W & & & & & \\
\hline \multirow{4}{*}{ Methanosaeta } & \multirow{4}{*}{$\begin{array}{l}\text { Acetoclastic } \\
\text { methanogens }\end{array}$} & DQOA6 & 24 & 22 & 19 & 65 & 25.8 & Uncultured archaeon (FJ638506) & $\begin{array}{l}\text { Methanosaeta thermophila } \\
\text { PT (CP000477) }\end{array}$ & $98(98)$ \\
\hline & & DQOA7 & 21 & 21 & 22 & 64 & 25.4 & $\begin{array}{l}\text { Uncultured archaeon } \\
\text { (DQ867049) }\end{array}$ & $\begin{array}{c}\text { Methanosaeta thermophila } \\
\text { PT (CP000477) }\end{array}$ & $96(96)$ \\
\hline & & DQOA3 & 12 & 12 & 9 & 33 & 13.1 & Methanosaeta sp. (DQ005715) & $\begin{array}{l}\text { Methanosaeta thermophila } \\
\text { ST-MET-2 (DQ005715) }\end{array}$ & $99(99)$ \\
\hline & & DQOA103 & & & 2 & 2 & 0.8 & Uncultured archaeon (FJ638512) & $\begin{array}{l}\text { Methanosaetathermophila } \\
\text { ST-MET-2 (DQ005715) }\end{array}$ & $98(97)$ \\
\hline \multirow{2}{*}{ Methanolinea } & \multirow{2}{*}{$\begin{array}{l}\text { Hydrogenotrophic } \\
\text { methanogens }\end{array}$} & DQOA10 & 10 & 7 & 16 & 33 & 13.1 & $\begin{array}{l}\text { Methanolinea tarda } \\
\text { (NR_028163) }\end{array}$ & $\begin{array}{l}\text { Methanolinea tarda } \\
\text { NOBI-1 (NR_028163) }\end{array}$ & $96(96)$ \\
\hline & & DQOA35 & 5 & 2 & 9 & 16 & 6.3 & $\begin{array}{l}\text { Methanolinea tarda } \\
\text { (NR_028163) }\end{array}$ & $\begin{array}{l}\text { Methanolinea tarda } \\
\text { NOBI-1 (NR_028163) }\end{array}$ & $99(99)$ \\
\hline \multirow[t]{2}{*}{ Crenarchaeota } & & DQOA12 & 5 & 4 & 8 & 17 & 6.7 & $\begin{array}{l}\text { Uncultured Thermoprotei archaeon } \\
\text { clone NRA16 (HM041917) }\end{array}$ & $\begin{array}{l}\text { Thermofilum pendens Hvv3, } \\
\text { DSM } 2475 \text { (NR_029214) }\end{array}$ & $99(87)$ \\
\hline & & DQOA41 & & 3 & 2 & 5 & 2.0 & Uncultured archaeon (FJ784299) & & 99 \\
\hline
\end{tabular}

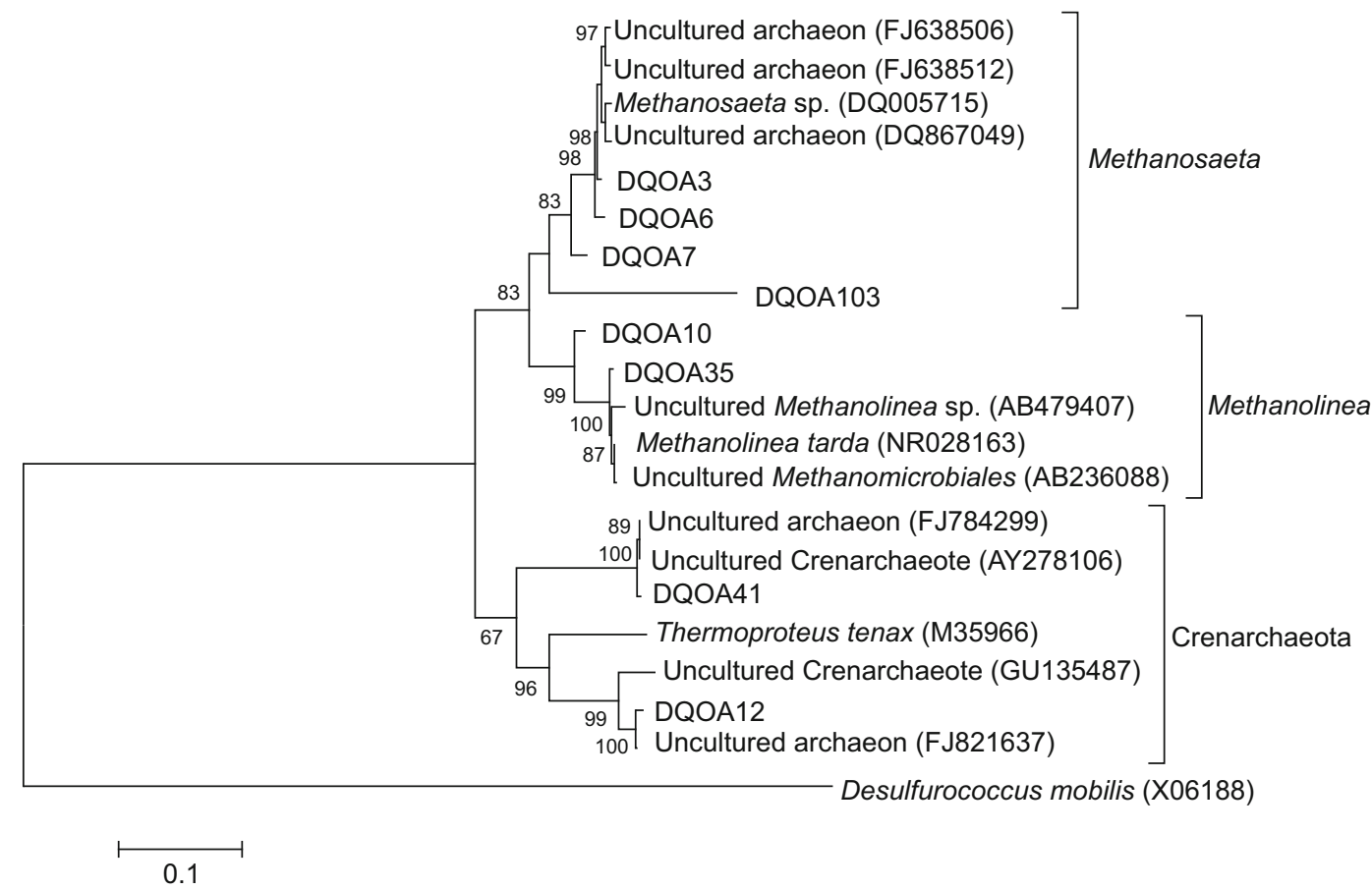

Fig. 3 Phylogenetic tree of sequenced archaeal OTUs 


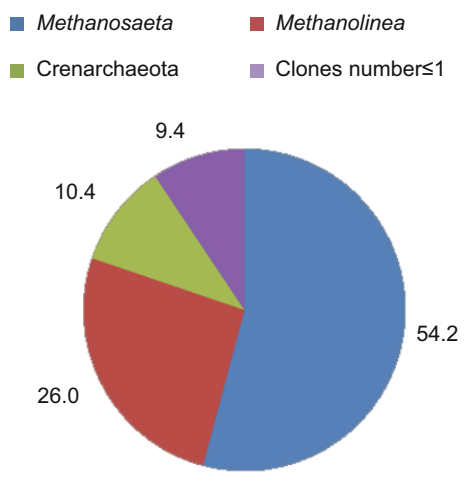

(a) Water flooding reservoir

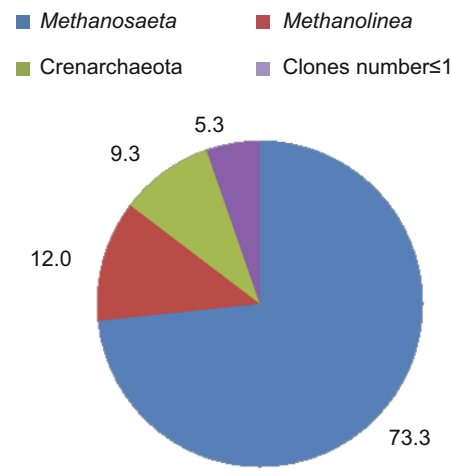

(b) Transitional zone

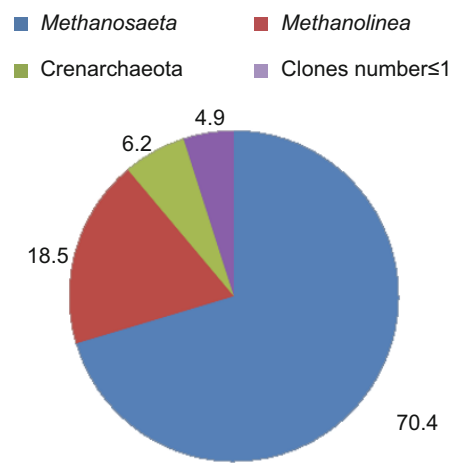

(c) Polymer flooding reservoir

Fig. 4 Relative contributions of different phylogenetic groups to archaeal communities

\subsection{Isolation and identification of functionally distinct groups}

In addition to the phylogenetic surveys, we used enrichment cultures to directly examine the metabolic diversity of functionally distinct isolates. Seven distinct groups were selected in this study, and the representative strains were listed in Table 5.

\subsubsection{Methanogens}

The cell numbers of cultivable methanogens were relatively low and varied between $10^{\circ}$ to $10^{2}$. The water flooding reservoirs have the highest cell number of methanogens. We randomly selected a total of 10 isolates from three samples for $16 \mathrm{~S}$ rDNA sequence analysis. Results showed that of the 10 sequences, 4 phylogenetic groups were identified. However, only two isolates from water flooding sample, identified as Methanothermobacter thermautotrophicus and Methanoculleus receptaculi respectively, were functionally related to methanogens. The other two phylopytes were phylogenetically associated with Tepidanaerobacter syntrophicus and Coprothermobacter proteolyticus.

\subsubsection{Fermenters}

The numbers of fermentative bacteria in produced water are relatively high and in the magnitude of $10^{4}$. A total of 107 isolates with variety of morphological types were selected and the 16S rDNA amplicons were screened by RFLP analysis (Rsa I and Hae III). Five unique phylotypes were obtained and one representative strains of each phylotype were selected for further $16 \mathrm{~S}$ rDNA sequencing. The representative isolates were highly similar ( $>98 \%)$ to known cultivated species, most of which have been previously isolated from oil-bearing ecosystems. The fermentative bacteria in the Daqing Oilfield were phylogenetically diverse in virtue of the fact that they fell within 5 different genera, which were identified as Pseudomonas, Haloanaerobium, Alcalibacter, Arcobacter, and Pannonibacter, respectively. Isolates with higher similarity (100\%) to Pseudomonas putida BBAL5-01 reside in both water flooding and polymer flooding reservoirs.

\subsubsection{Nitrate-reducing bacteria}

Nitrate-reducing bacteria recovered from the three produced water samples of the Daqing Oilfield were in a different order of magnitude. The transitional zone sample had the largest number of anaerobic nitrate-reducing bacteria. A total of 90 isolates were classified into 7 unique phylotypes by RFLP analysis. 16S rDNA sequence analysis of the representative strains of each phylotype indicated that isolates originated from water flooding reservoir demonstrated $97 \%$ to $100 \%$ similarity to genus Pseudomonas, but fell within different species. Four phylotypes were detected in polymer flooding reservoir, and isolates related to Pseudomonas putida BBAL5-01 were also present in water flooding reservoir. Only two distinct phylotypes were enriched from transitional zone. Of these two phylotypes, the isolates related to Pseudomonas stutzeri were also found in polymer flooding reservoir, despite the physicochemical differences between formations.

\subsubsection{Hydrocarbon oxidizing bacteria}

Medium with paraffin as the sole source of carbon was used for enrichment of hydrocarbon oxidizing bacteria (HOB). The number of indigenous HOB in produced water was only approximately $10^{1}$. A total of 90 isolates with variety of morphotypes were randomly selected and were clustered into 8 unique phylotypes by restriction enzyme digestion. One strain per phylotype was selected for partial 16S rDNA sequencing. Results indicated that most of the isolates were highly similar ( $>98 \%)$ to known cultivated species. Only one phylotype was identified from water flooding reservoir, and it was 98\% similar to Pseudomonas putida BBAL5-01. The HOBs in the polymer flooding reservoir are more diverse with 5 distinct phylotypes, and there was no overlap with the water flooding reservoir and transitional zone sample. But of these 5 phylotypes, 3 are affiliated to Micrococcus luteus with $100 \%$ similarity. Isolates originated from the transitional zone sample were clustered into 3 phylotypes, with one shared with water flooding reservoir.

\subsubsection{Biosurfactant producing bacteria}

Since biosurfactant producing bacteria usually have the haemolytic activity, haemolysis has been used as an initial criterion for the isolation of biosurfactant producing bacteria. Blood agar plate was used for primary enumeration of biosurfactant producing bacteria, and haemolytic activity was detected as the presence of a definite clear zone around a colony. The numbers of isolates with haemolytic activity originated from individual produced water are quite different. The polymer flooding reservoir and the transitional zone sample have a relatively high level of haemolytic isolates, 
Table 5 Functionally distinct groups isolated from produced water of the Daqing Oilfield

\begin{tabular}{|c|c|c|c|c|c|c|c|}
\hline \multirow{2}{*}{$\begin{array}{l}\text { Physiological and } \\
\text { functional types }\end{array}$} & \multicolumn{3}{|c|}{ Numeration cell $/ \mathrm{mL}$} & \multirow{2}{*}{$\begin{array}{c}\text { Representative } \\
\text { isolates }\end{array}$} & \multirow{2}{*}{ Source } & \multirow{2}{*}{ Closely related cultivated species (accession number) } & \multirow{2}{*}{$\%$ Similarity } \\
\hline & W & $\mathrm{P}$ & $\mathrm{T}$ & & & & \\
\hline \multirow{2}{*}{ Methanogens } & \multirow{2}{*}{$10^{2}$} & \multirow{2}{*}{$10^{1}$} & \multirow{2}{*}{$10^{0}$} & MW74 & W & Methanothermobacter thermautotrophicus (EF100758) & 99 \\
\hline & & & & MW90 & W & Methanoculleus receptaculi (DQ787476) & 99 \\
\hline \multirow{5}{*}{ Fermenters } & \multirow{5}{*}{$10^{3}$} & \multirow{5}{*}{$10^{4}$} & \multirow{5}{*}{$10^{4}$} & FW5 & $\mathrm{W}, \mathrm{P}$ & Pseudomonas putida BBAL5-01 (FJ217184) & 100 \\
\hline & & & & FW6 & $\mathrm{W}$ & Haloanaerobium acetoethylicum (U86448) & 99 \\
\hline & & & & FP49 & $\mathrm{P}$ & Alcalibacter saccharofermentans Z-79820 (AY312403) & 100 \\
\hline & & & & FT18 & $\mathrm{T}$ & Arcobacter halophilus LA31B (AF513455) & 98 \\
\hline & & & & FT23 & $\mathrm{T}$ & Pannonibacter phragmitetus 224 (EU841534) & 100 \\
\hline \multirow{7}{*}{$\begin{array}{l}\text { Nitrate-reducing } \\
\text { bacteria }\end{array}$} & \multirow{7}{*}{$10^{1}$} & \multirow{7}{*}{$10^{2}$} & \multirow{7}{*}{$10^{3}$} & DW9 & $\mathrm{W}, \mathrm{P}$ & Pseudomonas putida BBAL5-01 (FJ217184) & 98 \\
\hline & & & & DW20 & $\mathrm{W}$ & Pseudomonas brenneri B6 (AM989293) & 97 \\
\hline & & & & DW28 & $\mathrm{W}$ & Pseudomonas aeruginosa H1987 (FJ598142) & 100 \\
\hline & & & & DP26 & $\mathrm{P}, \mathrm{T}$ & Pseudomonas stutzeri PTG4-15 (AY998133) & 98 \\
\hline & & & & DP1 & $\mathrm{P}$ & Pantoea agglomerans 3I2 (FJ868806) & 98 \\
\hline & & & & DP2 & $\mathrm{P}$ & Enterobacter sakazakii E269 (EU780076) & 100 \\
\hline & & & & DT20 & $\mathrm{T}$ & Acinetobacter haemolyticus BA56 (EU841534) & 99 \\
\hline \multirow{8}{*}{$\begin{array}{c}\text { Hydrocarbon } \\
\text { oxidizing bacteria }\end{array}$} & \multirow{8}{*}{$10^{2}$} & \multirow{8}{*}{$10^{1}$} & & HW11 & $\mathrm{W}, \mathrm{T}$ & Pseudomonas putida BBAL5-01 (FJ217184) & 98 \\
\hline & & & & HP6 & $P$ & Pannonibacter phragmitetus LMG 5421 (AM269447) & 99 \\
\hline & & & & HP14 & $P$ & Paenibacillus ginsengagri TS IW 08 (AM992187) & 99 \\
\hline & & & $10^{1}$ & HP25 & $\mathrm{P}$ & Micrococcus luteus JL22 (EU418716) & 100 \\
\hline & & & 10 & HP24 & $\mathrm{P}$ & Micrococcus luteus H933 (FJ609696) & 100 \\
\hline & & & & HP20 & $\mathrm{P}$ & Micrococcus luteus EI-4 (FJ613533) & 100 \\
\hline & & & & HT17 & $\mathrm{T}$ & Pseudomonas pseudoalcaligenes 23 (EU780001) & 99 \\
\hline & & & & HT3 & $\mathrm{T}$ & Bacillus coagulans TR (FJ627946) & 100 \\
\hline & & & & BW21 & W & Bacillus thuringiensis NB8 (FJ686830) & 100 \\
\hline & & & & BW6 & $\mathrm{W}$ & Pseudomonas aeruginosa AKM-P6 (FJ654697) & 100 \\
\hline & & & & BW5 & $\mathrm{W}, \mathrm{T}$ & Agrococcus jenensis (EF111260) & 99 \\
\hline & & & & BW28 & W & Bacillus cereus (FJ608120) & 100 \\
\hline Biosurfactant & $10^{1}$ & $10^{4}$ & $10^{5}$ & BP25 & $\mathrm{P}, \mathrm{T}$ & Acinetobacter haemolyticus BA56 (FJ263930) & 99 \\
\hline producing bacteria & & & 10 & BP29 & $\mathrm{P}$ & Acinetobacter junii strain 824 (FJ544340) & 100 \\
\hline & & & & BP34 & $\mathrm{P}, \mathrm{T}$ & Pseudomonas putida BBAL5-01 (FJ217184) & 99 \\
\hline & & & & ВР39 & $\mathrm{P}, \mathrm{T}$ & Pseudomonas stutzeri PTG4-15 (EU603456) & 99 \\
\hline & & & & BT26 & $\mathrm{T}$ & Pannonibacter phragmitetus (FJ882624) & 100 \\
\hline & & & & BT20 & $\mathrm{T}$ & Bacillus pumilus (GQ202133) & 100 \\
\hline & & & & PW7 & $\mathrm{W}, \mathrm{P}$ & Pseudomonas putida BBAL5-01 (FJ217184) & 100 \\
\hline & & & & PW9 & $\mathrm{W}, \mathrm{P}$ & Pseudomonas stutzeri 13636M (EU741093) & 99 \\
\hline & & & & PW5 & $\mathrm{W}, \mathrm{P}, \mathrm{T}$ & Pseudomonas stutzeri PTG4-15 (EU603456) & 99 \\
\hline & & & & PW3 & $\mathrm{W}, \mathrm{P}$ & Acinetobacter haemolyticus DSM 6962 (NR026207) & 99 \\
\hline $\begin{array}{l}\text { Polymer producing } \\
\text { bacteria }\end{array}$ & $10^{4}$ & $10^{5}$ & $10^{5}$ & PP2 & $\mathrm{P}, \mathrm{T}$ & Alishewanella aestuarii B11 (EF660759) & 100 \\
\hline & & & & PT6 & $\mathrm{T}$ & Bacillus licheniformis YP1A (EF105377) & 100 \\
\hline & & & & PT2 & $\mathrm{T}$ & Bacillus licheniformis HNL09 (EU373344) & 100 \\
\hline & & & & PT14 & $\mathrm{T}$ & Bacillus cereus DC3 (GQ344805) & 100 \\
\hline & & & & PT21 & $\mathrm{T}$ & Bacillus licheniformis P79 (FJ808719) & 99 \\
\hline & & & & AW1 & $\mathrm{W}, \mathrm{P}, \mathrm{T}$ & Pseudomonas stutzeri ATCC 17594 (AY905607) & 99 \\
\hline & & & & AW13 & $\mathrm{W}, \mathrm{P}, \mathrm{T}$ & Pseudomonas putida BBAL5-01 (FJ217184) & 100 \\
\hline Polyacrylamide & $10^{1}$ & $10^{3}$ & $10^{4}$ & AW29 & W & Pseudomonas sp. 80 GUDO (FJ626690) & 99 \\
\hline degrading bacteria & & & & AW30 & W & Bacillus subtilis EIV-23 (FJ613581) & 100 \\
\hline & & & & AP12 & $P$ & Pseudomonas mendocina DS04-T (FJ426615) & 100 \\
\hline & & & & AP14 & $\mathrm{P}$ & Pseudomonas lubricans SF168 (FJ600733) & 99 \\
\hline
\end{tabular}


while the haemolytic isolates in water flooding reservoir are only in the magnitude of $10^{1}$.

A total of 60 isolates with haemolytic activity were screened by RFLP analysis and 10 unique phylotypes were distinguished. Isolates with distinct digestion patterns were further identified by $16 \mathrm{~S}$ rDNA sequencing. Although there are physicochemical differences among three water samples, isolates with identical RFLP patterns were isolated from different water samples. Isolate with higher similarity (99\%) to Agrococcus jenensis were presented in both water flooding reservoir and transitional zone, and isolates associated with Acinetobacter haemolyticus BA56, Pseudomonas putida BBAL5-01, and Pseudomonas stutzeri PTG4-15 were shared by samples from polymer flooding reservoir and transitional zone.

However, not all isolates with haemolytic activity can produce biosurfactants. Preliminary tensiometer studies revealed that, of the 10 representative isolates listed in Table 5, only BW6, BW21, BP25, BP29, BP34 showed the ability for biosurfactant production. After $36 \mathrm{~h}$ incubation, the surface tension of the growth medium was reduced from initial values of $60.2 \mathrm{mN} \cdot \mathrm{m}^{-1}$ to $25.6,37.9,38.4,38.6$, and $39.5 \mathrm{mN} \cdot \mathrm{m}^{-1}$ in cell free media by BW6, BW21, BP25, BP29, and BP34, respectively.

\subsubsection{Biopolymer producing bacteria}

Biopolymer producing bacteria have important applications in oil recovery by selective plugging the high-permeability thief zones. In this study, basal mineral salt medium supplemented with sucrose were used for cultivation of presumed polymer producing bacteria. Wet and viscous colonies were picked up and preliminarily considered as biopolymer producing bacteria. The numbers of biopolymer producing bacteria in all three samples were nearly in the same order of magnitude (approximately $10^{5}$ cells per milliliter). Ninety isolates were clustered into 9 phylotypes by RFLP analysis, with 4 from the water flooding reservoir, 5 from the polymer flooding reservoir, and 6 from the transitional zone. 16S rDNA sequence analysis of the representative strains of each phylotype showed that most biopolymer producing bacteria in the water flooding and polymer flooding reservoirs are phylogeneticly associated with Pseudomonas, while transitional zone was dominated by Bacillus.

Preliminary detection of the capacity for biopolymer production showed that 5 representative isolates could contribute positively to an increase of broth viscosity after 5-day fermentation. The viscosity of the broth could be increased from original value of 1.34 maps to $1,414,300.4$, 1,274, 192.2, and 230.5 maps by PW5, PW7, PW9, PT6, and PT21, respectively.

\subsubsection{Polyacrylamide degrading bacteria}

Enrichment of HPAM degrading bacteria with HPAM as the sole source of carbon and nitrogen led to the isolation of strains phylogenetic associated with Pseudomonas, but which were from different species. The cell number of HPAM degrading bacteria in the polymer flooding reservoir and the transitional zone were much higher than that in the water flooding reservoir. This may partly due to the selective pressure of the high concentration of HPAM that had been injected into that reservoir.

The preliminary detection of HPAM degrading capacity by viscometer showed that, the HPAM removing efficiency of most representative strains ranged from $30 \%$ to $45 \%$ (detailed data were not shown). While, strain AP14 could be taken as the most promising HPAM-degrading bacteria with the degradation rate of up to $71.1 \%$.

Interestingly, some isolated strains were simultaneously detected in different functional groups, and even more, from different produced water samples. The most common strain was the isolates (FW5, DW9, HW11, BP34, PW7, and AW13) closely related to Pseudomonas putida BBAL5-01, which was found in all the tested functional groups except Methanogens. The isolates affiliated to Pseudomonas stutzeri PTG4-15 (DP26, BP39, and PW5) were identified as nitratereducing bacteria, biosurfactant-producing bacteria, and polymer-producing bacteria. Acinetobacter haemolyticus BA56 represented by DT20 and BP25 was functionally related to both nitrate-reducing and biosurfactant-producing bacteria.

\section{Discussion}

The objective of this study was to investigate the microbial community structure and functionally distinct groups of a mesothermic oil-bearing formation in the Daqing Oilfield, which has slightly alkaline and low-salinity production water. However, this kind of mesothermic (45 $\left.{ }^{\circ} \mathrm{C}\right)$ petroleum system is not widespread in China. Actually, most of the oil fields in China are characterized as hightemperature petroleum reservoirs. The fluid temperature of the Huabei Oilfields (located in the central part of China) is up to $75^{\circ} \mathrm{C}$ (Li et al, 2007); and that of the Dagang Oilfields (also located at the central part of China) varied between 55$90{ }^{\circ} \mathrm{C}$ (She et al, 2005; Nanita et al, 2006). The formation temperature in the Shengli Oilfield (located at eastern coast of China) ranged from 60 to $80{ }^{\circ} \mathrm{C}$ (Yuan et al, 2008). Moreover, to our knowledge there are few such mesothermic petroleum reservoirs distributed in all over the world (Pham et al, 2009). They have been grouped either into hightemperature or into low-temperature oil reservoirs (BonchOsmolovskaya et al, 2003; Grabowski et al, 2005; Orphan et al, 2000; Voordouw et al, 1996). Consequently, this unusual and significant petroleum ecosystem must be associated with a unique microbial composition, which has not yet been well characterized before.

\subsection{Microbial community composition in the Daqing Oilfield and comparison with organisms previously detected in oil affiliated samples}

Compared to soils, sludge, and some other environmental samples, the microbial diversity is comparatively low in produced water samples from the petroleum reservoir. The bacterial and archaeal diversities ( $\mathrm{S}-\mathrm{W}$ index) calculated based on ARDRA analysis varied from 1.66 to 2.76 in produced water from the Daqing Oilfield (Table 2). This apparently low diversity might be attributed to the extreme conditions of the subsurface petroleum reservoir environment. The water flooding reservoir had a relatively high bacterial and archaeal diversity compared with polymer flooding 
reservoir and transitional zone samples (Table 2), which may have resulted from the selective pressure of polymer injected into the oil reservoir. Bacterial composition in the water flooding reservoir, polymer flooding reservoir, and transitional zone 16S rDNA libraries revealed a marked disparity in representation, with Acinetobacter as the dominant group in the water flooding and polymer flooding reservoir libraries, and phylotypes related to Arcobater as the dominant member in the transitional zone library. This may due partly to the different oil recovery manner and the physicochemical heterogeneity. While in contrast with the bacterial composition, the archaeal community structures of the three produced water samples are quite similar. This may be explained by the fact that methanogenesis, mediated by methanogens, is the terminal process of the oil reservoir food chain and thus, the influence of oil field exploitation on the methanoarchaeal community is very small.

The bacterial 16S rDNA gene library of the formation fluids from the Daqing Oilfield was dominated by known mesophilic (Acinetobacter and Pseudomonas) genera, rather than thermophilic microorganisms usually founded in hightemperature petroleum system. The first reason may lie in the shallow, mesothermic reservoir conditions in the Daqing Oilfield. Additionally, the water flooding operation has been continued for more than 40 years, which implies that it is an open system. The injection water was recycled from the water produced from the reservoir and was not sterile during this operation; therefore a number of microorganisms originally present in the surface environment may have been introduced into the reservoir along with the re-injected water. Some microorganisms may remain in the cooler portions of the reservoir, such as in the bottoms of injection wells, or along the wall of production wells (Orphan et al, 2000).

Acinetobacter-related clones appeared to be the most dominant members in bacterial community of the produced water samples from the Daqing Oilfield. This genus has been previously detected in high-temperature, sulfur-rich oil reservoirs in California (Orphan et al, 2000), but not as the predominant group. Pseudomonas-like clones seems to be a common component of oil-bearing subsurface environments in Chinese petroleum systems. The proportion of Pseudomonas in total bacterial clones is up to $62 \%, 80.7 \%$, and $85.5 \%$ in Dagang, Huabei, and Shengli Oilfields, respectively (She et al, 2005; Li et al, 2007; Yuan et al, 2008). This genus has also been found in a number of high-temperature and low-temperature petroleum reservoirs worldwide (BonchOsmolovskaya et al, 2003; Orphan et al, 2000; Pham et al, 2009). Pseudomonas has a broad range of metabolic capabilities and probably plays a role in the trophic web of oil-bearing ecosystems, which may explain their widespread distribution and frequent detection.

Arcobacter-related clones were second in abundance in the bacterial library and were only detected in transitional zone samples. High proportions of Arcobacter-related phylotypes have been frequently reported in 16S rDNA libraries from oil field produced water and petroleum-related environments (Grabowski et al, 2005; Pham et al, 2009; Voordouw et al, 1996; Sette et al, 2007). Interestingly, the bacterial community of produced waters in a low-temperature biodegraded oil reservoir in Canada was entirely composed of sequences highly similar to a 16S rRNA gene sequence from Arcobacter genus (Grabowski et al, 2005). Some members in genera Arcobacter were presumed to be functionally related with nitrate reduction and sulfide oxidation (Voordouw et al, 1996; Sette et al, 2007). The apparent abundance of these Arcobacter-related phylotypes implied that their corresponding organisms might contribute to nitrogen and sulfur cycles in oil reservoirs, especially in the transitional zone.

The only described species within the phylum Firmicutes is closely affiliated with Moorella thermoacetica, which was identified from the transitional zone sample. Moorella thermoacetica, formerly described as Clostridium thermoaceticum, was originally isolated from thermal habitats (Drake and Daniel, 2004), but not yet described from oil reservoir systems. Moorella thermoacetica was also considered as a model acetogenic bacterium that has been widely used for elucidating the Wood-Ljungdahl pathway of $\mathrm{CO}$ and $\mathrm{CO}_{2}$ fixation. Sulfurospirillum was only detected in the water flooding reservoir library, and the members from this genus were mainly related to functional groups targeting nitrate-reducing and sulfide-oxidizing bacteria (Hubert and Voordouw, 2007).

Methanogen phylotypes are the frequently detected members in the archaeal library from subsurface oil reservoir ecosystems. Methanomicrobia-related clones can utilize $\mathrm{H}_{2}+$ $\mathrm{CO}_{2}$ or acetate as the sole energy source, and have contributed to methane production in most petroleum reservoirs. Members of the acetoclastic genus Methanosaeta were identified as the most dominant group in archaeal libraries of produced water from the Daqing oil field, followed by hydrogenotrophic genus Methanolinea, and some unknown Crenarchaeotes. Two phylotypes revealed from Methanosaeta were closely related with cultivated species Methanosaetathermophila sp. ST-MET-2 (Table 3), which has been previously isolated from oil storage tanks (Kaster and Voordouw, 2006). Methanosaeta thermophila is known as a thermophilic obligatelyaceticlastic methane-producing archaeon, and present in many anaerobic habitats, such as anaerobic digesters, anaerobic biofilms, sediments, and sludges (Kamagata et al, 1992). However, no strains of this species have so far been isolated from oil reservoir samples. One of the phylotypes detected in phylum Crenarchaeota showed low similarity (87\%) with thermophilic member Thermofilum pendens Hvv3, DSM 2475, which has been previously isolated from produced fluid from Niiboli Oilfield (Kjems et al, 1990). It could be deduced that thermophilic members were one of the dominant groups in the archaeal library of the Daqing oil reservoir ecosystem, which indicates that these phylotypes might be the "true" indigenous microorganisms residing in deep-surface oil reservoirs, not introduced by injection water. The phylotypes detected in phylum Crenarchaeota which could not be affiliated with or showed low similarity with the known species suggested that the microbial community in the Daqing Oilfield may harbor novel archaeal genera or species.

In most of the previous studies, hydrogenotrophic 
methanogens were usually considered as the dominant methanoarchaeal lineages in oil-bearing environments (Magot et al, 2000; Orphan et al, 2000; Grabowski et al, 2005). However, the prominence of acetoclastic methanogens has also been discussed by several previous studies, which coincide with our results. Groups related to the acetoclastic genus Methanosaeta have been previously reported as the one of the dominant methanogens in a low-temperature Canadian petroleum field (Grabowski et al, 2005). Pham et al (2009) also indicated that relatives of acetoclastic methanogens outnumbered lithotrophic methanogens by ratios of $6: 1$ in an Alaska mesothermic petroleum reservoir. Here, we have shown that both hydrogenotrophic and acetoclastic methanogens were present in the produced water and were likely to have contributed to methane production in the Daqing oil reservoir. But acetoclastic methanogenesis may serve as a rather more important, and perhaps dominant, terminal electron sink in this ecosystem.

\subsection{The cultivated functional strains and comparison to $16 \mathrm{~S}$ rDNA directly recovered in libraries}

The functionally distinct groups were isolated from produced water with the selective culture method, and the cultured assemblages were compared to the community profiles generated from cloned SSU rDNAs.

The two cultivated methanogens isolated by the rolltube method did not match the dominant methanogenic OTUs generated from the archaeal library at the genuslevel. The dominant methanoarchaeal lineages obtained by the culture-independent method were affiliated with the genus Methanosaeta and Methanolinea (Table 3), while, the two cultivated methanogens isolated from water flooding sample were clustered within Methanothermobacter and Methanoculleus (Table 5). But Methanoculleus, Methanosaeta and Methanolinea are all clustered within class Methanomicrobia, and even more, Methanoculleus and Methanolinea are both affiliated in order Methanomicrobiales. Methanothermobacter thermautotrophicus has been previously detected in high-temperature oil reservoir systems (Li et al, 2007; Nazita, 2006). Actually, another two clones with distinct phylotypes had been simultaneously isolated with the roll-tube technique in this study. 16S rDNA analysis of these two isolates showed that they were phylogeneticly associated with Tepidanaerobacter syntrophicus (AB106354, 99\%) and Coprothermobacter proteolyticus (CP001145, $99 \%$ ). These two isolates are not "true" methanogens, but are the potential partner bacteria of methanogens in the process of methanogenic degradation by syntrophic cooperation (Etchebehere et al, 1998; Sekiguchi et al, 2006). It is difficult to explain the failure of isolation of methanogens from water samples obtained from polymer flooding reservoirs and the transitional zone.

The most dominant phylogenic division generated from bacterial libraries was closely related to genus Acinetobacter, with Acinetobacter johnsonii as the most frequent detected species (Table 3). However, no cultivated functional strains isolated in this study were affiliated with Acinetobacter johnsonii. Additionally, Acinetobacter haemolyticus, which was absent from bacterial library, has been detected in several types of functional groups (nitrate-reducing, biosurfactantproducing and polymer-producing groups). Only phylotypes identified as Acinetobacter junii were detected both in enrichments (biosurfactant-producing strain BP29) and in $16 \mathrm{~S}$ rDNA clone libraries (OTU DQOB18) (Tables 3 and 5).

A significant percentage of Pseudomonas in the bacterial library was determined as Pseudomonas stutzeri based on the closest matched cultivated species, but with relatively low similarities $(<97 \%)$ (Table 3 ). Representative isolates closely $(\geq 98 \%$ ) related to Pseudomonas stutzeri were widespread in different functional groups, including fermentative, nitratereducing, biosurfactant-producing, polymer-producing, and polyacrylamide degrading bacteria. However, these cultured Pseudomonas stutzeri isolates only showed species-level similarity due to the fact that they had different strains as the closest match (Table 5). Interestingly, Pseudomonas putida and some other species in genus Pseudomonas, which have been frequently enriched by selective medium, were not detected by the culture-independent method.

Despite the high percentage of $16 \mathrm{~S}$ rDNA clones of Arcobater in the bacterial library, only one Arcobater-related isolate was retrieved as a fermentative bacteria. Also, there was no overlap between the $16 \mathrm{~S}$ rDNA phylotypes in the bacterial library and the isolates closely related to several species in Bacillus, Micrococcus luteus, and Pannonibacter phragmitetus, although they had common occurrence in the majority of cultivated functional groups.

The facts described above indicated that the cultivation and molecular-based approaches each sampled a different subset of the community. The lack of cultivated isolates in clone libraries may indicate that these fast-growing organisms are not a dominant component of the in situ reservoir assemblage. Alternatively, they may have been missed due to PCR biases in the mixed assemblage DNA amplification, although the universal primers used were found to be compatible with the 16S rDNA sequences in the database. On the other hand, it is not difficult to explain the negative enrichments of the dominant groups detected in clone libraries. First, maybe they are not functionally related to any phynotypical groups tested in this study. And secondly, even if they were associated with certain functional groups, maybe they are "uncultured" or "difficult cultured" ones due to the medium and incubation conditions we selected. Taking Arcobacter and Sulfurospirillum for example, members of these two genera are possibly involved in the process of nitrate reduction and sulfide oxidation. However, they had not been isolated from the produced water samples by the culture conditions selected in this study. To obtain more comprehensive information on the indigenous functional groups in oil reservoir, substantial efforts for cultivation of the "uncultured" microorganisms will be necessary.

\subsection{Potential use of indigenous isolates in oil field (especially in MEOR)}

The first production from an oil well is the result of the pressure of the earth's overburden on the oil-bearing formation or by pumping. As this primary production 
declines, some of the wells are converted to injection wells and either water flooding or sometimes gas flooding operations are implemented. Even after this secondary production effort has reached its economic limit, two-thirds of the original oil in place is still left in the ground and tertiary measures may be employed. These include chemical enhanced oil recovery (CEOR) methods such as polymer flooding, surfactant flooding, alkaline flooding, etc. or the use of thermal measures such as injection of steam or in situ combustion. However, CEOR methods turned out to be economically unattractive as the finished products are utilized for the recovery of raw materials. This is why scientists looked for a cost-effective alternative and discovered the same in MEOR, which exploits microorganisms for the production of all the chemicals as mentioned above. MEOR, to be economically viable, demands the use of microbial strains, which have the ability to produce biosurfactants, biopolymers, acids, gases and solvents to perform the job of recovering residual oil by fermenting cheaper raw materials, e.g. molasses (Sen, 2008).

Methanogens and fermentative bacteria are widely distributed in low and high temperature oil fields (BonchOsmolovskaya et al, 2003; Orphan et al, 2000; Stetter et al, 1993). They can ferment carbohydrates to produce gases such as $\mathrm{CH}_{4}, \mathrm{O}_{2}$ and $\mathrm{H}_{2}$, and thus, can contribute to pressure build-up in a pressure-depleted reservoir and reduce viscosity of crude oil. Additional effects of this bacteriainduced fermentation process include the production of acids, such as acetic and propionic acids and the production of solvents, such as acetone, ethanol, 1-butanol and butanone. Both gases and solvents can dissolve the carbonate rock, thereby increasing its permeability and porosity (Brown, 2010). Methane production activity of the two indigenous methanogens isolated from this study, Methanothermobacter thermautotrophicus MW74 and Methanoculleus receptaculi MW90, were primarily tested by anaerobic cultivation and the gas chromatography determination. Results suggested that strain MW74 can utilize acetate under low $\mathrm{pH}$ condition $(\mathrm{pH}=6)$, and can oxidize hydrogen to produce methane at relatively high $\mathrm{pH}(\mathrm{pH}=9)$. Isolate $\mathrm{MW} 90$ can only utilize $\mathrm{H}_{2}$ as the substrate (unpublished data).

Biosurfactants play a major role in MEOR by reducing interfacial tension (IFT) and also by altering the wettability of reservoir rock for water-flood to displace more oil from the capillary network. Microorganisms which can produce biosurfactants usually phylogenitically associated with Pseudomonas, Bacillus, Arthrobacter, Rhodococcus, and so on. In our research, surface activity studies revealed that Pseudomonas aeruginosa BW6 was the most promising biosurfactant-producing strain. Biosurfactants produced by this strain could reduce the surface tension of the broth from 60.2 to $25.6 \mathrm{mN} \cdot \mathrm{m}^{-1}$ after $36 \mathrm{~h}$ of growth. The biosurfactants were found to be functionally stable at varying $\mathrm{pH}$ (2.511) conditions and temperature of $100{ }^{\circ} \mathrm{C}$. The chemical structure of the biosurfactants produced by BW6 was preliminarily determined as rhamnolipid by TLC (thin layer chromatography) and NMR (nuclear magnetic resonance) (unpublished data). More powerfully and meaningfully, in our preliminary experiment, BW6 could produce biosurfactants under anaerobic conditions, and thus provide the possibility of in situ production of biosurfactants in the oil reservoir.

Biopolymers have been used in MEOR experiments mainly for selective plugging of oil-depleted zones and hence, for permeability modification (Sen, 2008). In selective plugging approaches, biopolymers plug high-permeability thief zones to redirect the injection water to low permeability zones. This is an adjunct to water-flooding operations, in which water is pumped into injection wells in the reservoir in order to force the oil up to the surface bypassing the oildepleted zones in the reservoir. Bacteria and/or nutrients preferentially enter the reservoir along high-permeability pathways. Biomass growth in those laminae plugs the pore throats, thus decreasing the permeability in what had once been the high-permeability zones. In our preliminary results, the viscosity of the growth medium could be dramatically increased from 1.34 to $1414 \mathrm{mPa} \cdot \mathrm{s}$ by the most promising isolate Pseudomonas stutzeri PW5. However, extensive research should be focused on the chemical structure analysis and optimization of the fermentation process.

Hydrocarbon-oxidizing bacteria are widely used in the oil-production industry for initiating oil biodegradation in overexploited oil reservoirs. The growth of HOB is accompanied by the formation of some compounds that exhibit oil-displacing properties $\left(\mathrm{CO}_{2}\right.$, organic acids, alcohols, biopolymers, surfactants, and others); this may be used as a basis for the development of biotechnologies for the enhancement of oil recovery (Rozanova and Nazina, 1982). It has also been used in the control of paraffin deposition in production wells and bioremediation of contamination caused by crude oil. The $n$-alkane degradation capacities of the 8 representative strains isolated in this research were primarily determined by the gravimetric method. Results showed that the $1 \%(\mathrm{v} / \mathrm{v})$ liquid paraffin could be degraded by more than $80 \%$, with Pseudomonas putida HW11, Micrococcus luteus HP25, and Pseudomonas pseudoalcaligenes HT17 (unpublished data). This in itself was very promising, since the degradation conditions have not yet been optimized.

Hydrolyzed polyacrylamide (HPAM) is extensively applied in tertiary oil recovery in the Daqing Oilfield. The discharge of wastewater containing high concentrations of HPAM will result in some severe environmental problems. Thus, effective decomposition of HPAM is an important issue when HPAM is used as a driver for oil exploitation. The HPAM removing efficiency of the most effective HPAM degrading strain isolated from the present study, Pseudomonas lubricans AP14, could reach up to $71.1 \%$. It was much higher than previous reports (Kunichika and Shinichi, 1995; Ma et al, 2008) and hence, could be a most promising candidate for treatment of HPAM-containing wastewater produced by polymer flooding recovery.

As well documented, sulphate-reducing bacteria (SRB) contribute to microbiologically influenced corrosion (MIC) of steel and steel alloys by production of the toxic and corrosive gas hydrogen sulphide $\left(\mathrm{H}_{2} \mathrm{~S}\right)$ during secondary oil recovery. SRB activity in the reservoir also leads to souring, which again leads to poor gas quality and oil-water 
separation problems. Traditionally, biocides have been used to control SRB activity. Introduction of nitrate and nitratereducing bacteria into oil reservoir has been proposed as a cost effective and an environmentally friendly method to control MIC and biogenic reservoir souring, by accumulation of the toxic reduction product nitrite and increased redox potential due to chemical (by nitrite) and biological (by nitrate reducing-sulfide oxidizing bacteria) oxidation of sulfides. Seven representative NRBs isolated from this study were clustered within 4 distinct genera. Some members in genus Enterobacter, Pseudomonas and Acinetobacter are frequently isolated as the NRB (Li et al, 1997; Nazina et al, 2000). However, Pantoea has not yet been reported to be functionally related with nitrate reduction. The denitrification abilities of the NRB isolated in this research work were preliminarily examined by inoculating them into NB broth using Durham tubes and incubating at $30{ }^{\circ} \mathrm{C}$ for a week. Growth of the representative NRB strains in NB broth was accompanied by a considerable decrease in the concentration of nitrates $(2,000 \mathrm{ppm}$ nitrate was nearly $100 \%$ removed from the broth). Among the products of nitrate reduction, we detected nitrite and molecular nitrogen (unpublished data). Further pilot experiments in the Daqing Oilfield indicated that the introduction of NRB strain Pseudomonas putida DW9 together with nitrate could dramatically inhibit the sulfide production (nearly $100 \%$ of sulfide was removed from the produced water), reduced the total SRB amount (down to 100 cell/L), as well as decreasing the corrosion rate (from 0.465 to $0.058 \mathrm{~g} \cdot \mathrm{m}^{-2} \cdot$ day $^{-1}$ ) (unpublished data).

Because of their detrimental effects, SRB have been the most commonly studied bacterial group from oil field water. However, this specific group was not involved in this study, since our study was aimed at revealing the "good" indigenous microorganisms in the Daqing oil reservoir, but not the "bad guys". Actually, the composition of SRB in the Daqing Oilfield has been previously studied by Wei et al (2010), and results showed that SRB members were mainly consisted of Desulfovibrio sp. and Desulfovibrio profundus. In our previous work, one SRB strain, which was identified as Garciella nitratireducens, was isolated from formation water produced by water flooding process in the Daqing Oilfield (Wang et al, 2008).

What should be considered is the widespread occurrence of close relatives to Pseudomonas putida BBAL5-01 within varying functional groups (nitrate-reducing bacteria, fermentative bacteria, and biosurfactants and biopolymer producing bacteria, and also, polyacrylamide degrading bacteria). It indicates that it may be a common indigenous bacteria in petroleum reservoirs and may have a significant impact on biogeochemical cycles in oil reservoirs. Extensive research is required for physical and biochemical characterization of this specific strain, and the metabolic mechanisms for its ecological function should be further studied.

\section{Conclusions}

Using both $16 \mathrm{~S}$ rDNA phylogenetic surveys and culture based methods, the present study, for the first time, systematically evaluated the composition of microbial communities and indigenous functional groups associated with a shallow, mesothermic and low-salinity oil reservoir in the northeast of China. Based on their 16S rRNA gene sequences, several lineages did not match the cultured isolates exactly, which implies they may be annotated as the new phylotypes. A vast pool of promising strains with distinct functions were isolated. It is believed that future studies of the function, interactions and ecological significance of these resident microorganisms will contribute to the promotion of applications in microbial enhanced oil recovery.

\section{Acknowledgements}

The project was financially supported by Chinese Academy of Science through the Knowledge Innovation Project of The Chinese Academy of Sciences (06LYQY3001). Funding for this project was also provided by Daqing Oilfield Co. Ltd., China.

\section{References}

Baker G C, Smith J J and Cowan D A. Review and re-analysis of domain-specific 16S primers. J. Microbiol. Methods. 2003. 55(3): 541-555

Bonch-Osmolovskaya E A, Miroshnichenko M L, Lebedinsky A V, et al. Radioisotopic, culture-based, and oligonucleotide microchip analyses of thermophilic microbial communities in a continental high-temperature petroleum reservoir. Appl. Environ. Microbiol. 2003. 69(10): 6143-6151

Brown L R. Microbial enhanced oil recovery (MEOR). Curr. Opin. Microbiol. 2010. 13(3): 316-320

Carrillo P G, Mardaraz C, Pitta-Alvarez S I, et al. Isolation and selection of biosurfactant-producing bacteria. World J. Microbiol. Biotechnol. 1996. 12(1): 82-84

Drake H L and Daniel S L. Physiology of the thermophilic acetogen Moorella thermoacetica. Res. Microbiol. 2004. 155(6): 422-436

Etchebehere C, Pavan M E, Zorzópulos J, et al. Coprothermobacter platensis sp. nov., a new anaerobic proteolytic thermophilic bacterium isolated from an anaerobic mesophilic sludge. Int. J. Syst. Bacteriol. 1998. 48(4): 1297-1304

Good I L. The population frequencies of species and the estimation of population parameters. Biometrika. 1953. 40(3-4): 237-264

Grabowski A, Nercessian O, Fayolle F, et al. Microbial diversity in production waters of a low temperature biodegraded oil reservoir. FEMS Microbiol. Ecol. 2005. 54(3): 427-443

Hubert $\mathrm{C}$ and Voordouw G. Oil field souring control by nitrate-reducing Sulfurospirillum spp. that outcompete sulfate-reducing bacteria for organic electron donors. Appl. Environ. Microbiol. 2007. 73(8): 2644-2652

Kamagata Y, Kawaski H, Oyaizu H, et al. Characterization of three thermophilic strains of Methanothrix ("Methanosaeta") thermophila sp. nov. and rejection of Methanothrix ("Methanosaeta") thermoacetophila. Int. J. Syst. Bacteriol. 1992. 42(3): 463-468

Kaster K M and Voordouw G. Effect of nitrite on a thermophilic, methanogenic consortium from an oil storage tank. Appl. Microbiol. Biotechnol. 2006. 72(6): 1308-1315

Kjems J, Leffers H, Olesen T, et al. Sequence, organisation and transcription of the ribosomal RNA operon and the downstream tRNA and protein genes in the archaebacterium Thermofilum pendens. Syst. Appl. Microbiol. 1990. 13(2): 117-127

Kunichika N and Shinichi K. Isolation of polyacrylamide-degrading bacteria. J. Ferment. Bioeng. 1995. 80(4): 418-420 
Lane D J. 16S/23S rRNA sequencing. In: Stackebrandt E and Goodfellow M, eds. Nucleic Acid Techniques in Bacterial Systematics. New York: John Wiley and Sons. 1991. 115-175

Li H, Duncan C, Townend J, et al. Nitrate-reducing bacteria on rat tongues. Appl. Environ. Microbiol. 1997. 63(3): 924-930

Li H, Yang S Z, Mu B Z, et al. Molecular phylogenetic diversity of themicrobial community associated with a high-temperature petroleum reservoir at an offshore oilfield. FEMS Microbiol. Ecol. 2007. 60(1): 74-84

Ma F, Wei L, Wang L, et al. Isolation and identification of the sulphatereducing bacteria strain $\mathrm{H} 1$ and its function for hydrolysed polyacrylamide degradation. Int. J. Biotechnology. 2008. 10(1): 5563

Magot M, Ollivier B and Patel B K C. Microbiology of petroleum reservoirs. Antonie van Leeuwenhoek. 2000. 77(2): 103-116

Nazina T N, Kosareva I M, Davidov A S, et al. Physicochemical and microbiological characteristics of groundwater from observation wells of a deep radioactive liquid waste repository. Microbiology. 2000. 69(1): 89-95

Nazina T N, Shestakova N M, Grigor'yan A A, et al. Phylogenetic diversity and activity of anaerobic microorganisms of hightemperature horizons of the Dagang oil field (PR China). Microbiology. 2006. 75(1): 55-65

Ollivier B, Cayol J L, Patel B K, et al. Methanoplanus petrolearius sp. nov., a novel methanogenic bacterium from an oil-producing well. FEMS Microbiol. Lett. 1997. 147(1): 51-56

Orphan V J, Taylor L T, Hafenbradl D, et al. Culture-dependent and culture-independent characterization of microbial assemblages associated with high-temperature petroleum reservoirs. Appl. Environ. Microbiol. 2000. 66(2): 700-711

Pham V D, Hnatow L L, Zhang S, et al. Characterizing microbial diversity in production water from an Alaskan mesothermic petroleum reservoir with two independent molecular methods. Environ. Microbiol. 2009. 11(1): 176-187

Rozanova E P and Nazina T N. Hydrocarbon-oxidizing bacteria and their activity in oil strata. Mikrobiologiya. 1982. 51(2): 342-348

Sekiguchi Y, Imachi H, Susilorukmi A, et al. Tepidanaerobacter syntrophicus gen. nov., sp. nov., an anaerobic, moderately thermophilic, syntrophic alcohol- and lactate-degrading bacterium isolated from thermophilic digested sludges. Int. J. Syst. Evol. Microbiol. 2006. 56(7): 1621-1629

Sen R. Biotechnology in petroleum recovery: The microbial EOR. Prog. Energ. Combust. 2008. 34(6): 714-724

Sette L D, Simioni K C M, Vasconcellos S P, et al. Analysis of the composition of bacterial communities in oil reservoirs from a southern offshore Brazilian basin. Antonie Van Leeuwenhoek. 2007. 91(3): 253-266

Shannon C E and Weaver W. The mathematical theory of communication. Urbana, IL: University of Illinois Press. 1949

She Y H, Zhang X L, Zhang F, et al. Molecular analysis of the microbial communities of the Dagang Kongdian flooding bed oilfield. Acta Microbiologica Sinica. 2005. 45(3): 329-334 (in Chinese)

Stetter K O, Huber R, Blochl E, et al. Hyperthermophilic archaea are thriving in deep North Sea and Alaskan oil reservoirs. Nature. 1993. 365(6448): 743-745

Voordouw G, Armstrong S M, Reimer M F, et al. Characterization of 16S rRNA genes from oil field microbial communities indicates the presence of a variety of sulfate-reducing, fermentative, and sulfideoxidizing bacteria. Appl. Environ. Microbiol. 1996. 62(5): $1623-$ 1629

Wang S H, Luo S P, Li B G, et al. Sequence analysis on physiological and biochemical characters of sulfate reducing bacteria strain EMZY-1 and 16S rDNA. Xinjiang Agricultural Sciences. 2008. 45(5): 801-804 (in Chinese)

Wei L, Ma F and Zhao G. Composition and dynamics of sulfate-reducing bacteria during the waterflooding process in the oil field application. Bioresource Technol. 2010. 101(8): 2643-2650

Yuan S Q, Xue Y F, Wang W D, et al. Characterization of bacterial diversity in the Shengli-S12 oil reservoir by culture-dependent and culture-independent methods. Acta Microbiologica Sinica. 2008. 48(8): 1082-1087 (in Chinese)

Zhang X M, She Y H, Huang J F, et al. Microbial diversity of the Daqing Oilfield after polymer flooding. Chinese Journal of Applied and Environmental Biology. 2008. 14(5): 668-672 (in Chinese)

(Edited by Sun Yanhua) 